\title{
Endothelial Cell Growth Promoting Activity in Graves' Disease Sera is Neutralized by Anti-Basic Fibroblast Growth Factor Antibodies in Patients with Fat Expansive but Not Infiltrative Orbitopathy
}

\author{
Mark B Zimering $\mathrm{MD}$, $\mathrm{PhD}^{1,2 *}$ John J Shin $\mathrm{MD}^{1,3}$, Jennifer D Zaitz $\mathrm{MD}^{3}$, Elkin A Nunez $\mathrm{MD}^{3}$ and Andrew G Gianoukakis $\mathrm{MD}^{4}$ \\ ${ }^{1}$ Veterans Affairs New Jersey Healthcare System, East Orange, New Jersey, USA \\ ${ }^{2}$ Rutgers-Robert Wood Johnson Medical School, New Brunswick, New Jersey, USA \\ ${ }^{3}$ Rutgers-New Jersey Medical School, Newark, New Jersey, USA \\ ${ }^{4}$ Division of Endocrinology, Harbor-UCLA Medical Center and the David Geffen School of Medicine at UCLA, Los Angeles, CA, USA
}

${ }^{*}$ Corresponding Author: Mark B Zimering MD, Medical Service (111), Veterans Affairs New Jersey Healthcare System, East Orange, NJ, USA; Tel: 908 647-0180; FAX: 908 604-5249; Email: mark.zimering@va.gov

Received: December 11, 2018; Accepted: December 21, 2018; Published: January 08, 2019;

\begin{abstract}
Purpose: To report a case of orbital fat expansion leading to globe prolapse in a Graves' disease patient undergoing high-dose glucocorticoid therapy. To evaluate the growth factor receptor specificities of plasma autoantibodies in Graves' disease patients who exhibited contrasting subtypes of thyroidassociated ophthalmopathy, i.e. orbital fat expansion-type $v$ s. infiltrative.

Methods: Sera from Graves' orbitopathy and control patients with or without Graves' disease were subjected to protein-A affinity chromatography to obtain immunoglobulin G. A $\left(1 / 50^{\text {th }}\right.$ to $\left.1 / 1600^{\text {th }}\right)$ range in dilutions of the protein-A eluate fraction was incubated for four days at 37 degrees $C$ with bovine pulmonary artery endothelial cells to test for endothelial cell inhibition or stimulation. Growth stimulatory autoantibodies were co-incubated with specific neutralizing anti-insulin like growth factor 1 receptor antibodies or anti-basic fibroblast growth factor antibodies to assess autoantibody specificity in contrasting Graves' orbitopathy subtypes.

Results: We observed increased mean endothelial cell growth promoting activity in the protein-A eluates of serum from eighteen patients with active Graves' disease $(117 \pm 28 \%, \mathrm{n}=18)$ compared to mean endothelial cell activity $(89 \pm 10 \%, \mathrm{n}=13, \mathrm{P}=0.003)$ in thirteen adults without Graves' disease. The protein-A eluate fraction in acute infiltrative-type Graves' orbitopathy contained a high titer $(>1: 1000)$ of endothelial cell stimulatory activity which was significantly neutralized by specific monoclonal anti-human insulin-like growth factor 1 receptor antibodies. The protein-A eluate fraction in fat expansion-type Graves' orbitopathy contained endothelial cell inhibitory activity (at low titers) and stimulatory activity (at high titers), and the latter stimulatory activity was completely neutralized by specific anti-basic fibroblast growth factor antibodies.
\end{abstract}

Conclusion: Graves' disease suffering globe prolapse secondary to marked orbital fat-expansion had coexisting plasma fibroblast growth factorinhibitory and -stimulatory autoantibodies. The latter was completely neutralized by anti-basic fibroblast growth factor antibodies.

Keywords: Graves' disease, thyroid associated ophthalmopathy, autoantibodies, fibroblast growth factor

\section{Introduction}

Thyroid-associated ophthalmopathy (TAO) is a vision-threatening complication of Graves' disease (GD) which can cause significant morbidity and impaired quality of life [1]. Extraocular muscle hypertrophy and local inflammation contribute to a severe infiltrative form of the disease whose underlying pathophysiology has been the focus of recent investigations [2]. Evidence suggests that increased local orbital glycosaminoglycan production (a hallmark in infiltrativetype Graves' orbitopathy) results (in part) from circulating agonist insulin- like growth factor 1 receptor autoantibodies [2] and increased expression of insulin-like growth factor 1 receptor (IGF- 1R) in orbital fibroblasts [3] and in T and B lymphocytes [4].
Orbital fat expansion can accompany Graves' extraocular muscle hypertrophy, but its underlying pathophysiology is less clearly defined. We report increased mean endothelial cell growth promoting activity in the protein-A eluates of serum from active Graves' disease compared to adult controls without GD. We also report a patient with type 2 diabetes mellitus, active Graves' disease, and focal segmental glomerulosclerosis (FSGS) who experienced acute globe prolapse secondary to severe orbital fat expansion in the setting of high-dose glucocorticoid therapy. The patient's orbitopathy was characterized by a lack of extra-ocular muscle enlargement and his plasma contained novel growth stimulatory endothelial cell plasma autoantibodies whose activity (in vitro) was completely neutralized by specific antibovine basic fibroblast growth factor (FGF) antibodies. These data 
suggest a possible role for circulating fibroblast growth factor-like autoantibodies in rare cases of Grave's orbitopathy characterized by pure orbital fat expansion.

\section{Participants and Methods}

\section{Participants}

Graves' disease (GD) Pt 1: A 45-year-old man with hyperthyroidism who presented with infiltrative-type orbitopathy, diplopia and a triiodothyronine (T3) level of $663 \mathrm{ng} / \mathrm{dL}$ (59- 174). He was treated with radioactive iodine (RAI) ablation, methylprednisolone and underwent orbital decompression surgery. Thyroid stimulating immunoglobulin was elevated at $194 \%(0-130)$ and anti-microsomal antibody was $4128 \mathrm{IU} / \mathrm{mL}(0-34)$.

Graves' disease (GD) Pt 2: A 53-year-old man with chronic Graves' disease (treated with tapazole), type 2 diabetes mellitus, macular edema, nephropathy, fat expansion-type orbitopathy and idiopathic focal segmental glomerulosclerosis (FSGS) for which the patient was treated with high- dose glucocorticoids. Thyroid stimulating immunoglobulin was elevated at 199\% (0-130) and anti-microsomal antibody was $2367 \mathrm{IU} / \mathrm{mL}(0-34)$. During steroid taper, the patient experienced prolapse of the right globe while driving his car. Magnetic resonance imaging of the orbits revealed markedly increased retrobulbar fat bilaterally with resulting proptosis. The extraocular muscles and optic nerves were normal. Doppler ultrasound of the thyroid revealed athyroid inferno pattern' suggestive of intrathyroidal angiogenesis. The patient progressed to end-stage-renal disease requiring dialysis and died suddenly of unknown causes six years later. Patient 3: A 72-year-old man with Graves' disease treated with methimazole. He experienced progression in orbitopathy (over a three-year period) characterized by marked enlargement in extraocular muscles and moderate increase in retrobulbar fat.

Patient 4: A 64-year-old man with type 2 diabetes, macular edema, and nephropathy who experienced bilateral supero-temporal orbital fat prolapse (left> right) within 9 months of receiving high-dose oral prednisone followed by intra-tympanic injection of solumedrol to treat autoimmune sensorineural hearing loss.

\section{Methods}

\section{Blood drawing/Protein-A Chromatography}

Informed consent for the local Institutional Review Boardapproved study was obtained from each participant prior to blood drawing which was performed in the morning. Protein-A affinity chromatography of serum was carried out as previously reported [5].

\section{Cell culture}

Bovine pulmonary artery (BPA) endothelial cells (EC) (Clonetics, Inc. San Diego, CA, USA) were maintained at $37^{\circ} \mathrm{C}$ in $5 \% \mathrm{CO} 2 / 95 \%$ air in Medium 199 (M199) plus 10\% fetal calf serum (FCS). BPA endothelial cells were passaged continuously and used between passages 4 and 7. Bovine pulmonary artery endothelial cells are exquisitely sensitive to low concentrations of basic fibroblast growth factor and are an optimal test system for the detection of fibroblast growth factor-like inhibitory and -stimulatory substances [5].

\section{Endothelial cell proliferation assays}

Endothelial cell number assays were carried out as previously reported [5]. Confluent cells were trypsinized and plated at 1 to $10 \times 103$ cells/well in Medium 199 plus 10\% fetal calf serum in 96- well plates. After 1 or 2 days incubation for cells to reach $60-80 \%$ confluency, test fractions $(30 \mu \mathrm{g} / \mathrm{mL}$ of the protein- A eluates of serum) were added to wells in quadruplicate. After 4 days' incubation in the presence of test fractions, cells were washed with phosphate- buffered saline and colorimetric estimation of cell number was determined as previously described [5]. Each point represents the mean of quadruplicate determinations.

\section{Antibodies}

Purified mouse monoclonal anti-human insulin-like growth factor-1 receptor antibodies were obtained from BD Biosciences (San Jose, CA). Polyclonal rabbit, anti-bovine basic fibroblast growth factor antibodies were obtained from R \& D Systems, Inc. (Minneapolis, $\mathrm{MN})$.

\section{Protein determinations}

Protein concentrations were determined by a bicinchoninic acid protein assay kit (Pierce Chemical Co., Rockford, IL, USA).

\section{Results}

\section{Graves' disease autoantibodies induce endothelial cell proliferation}

We observed increased mean endothelial cell growth promoting activity in the protein-A eluates of serum from eighteen patients with active Graves' disease $(117 \pm 28 \%, \mathrm{n}=18)$ compared to mean endothelial cell activity $(89 \pm 10 \%, \mathrm{n}=13, \mathrm{P}=0.003)$ in an identical 30 $\mu \mathrm{g} / \mathrm{mL}$ concentration of the protein-A eluate in thirteen adults without Graves' disease (including six normal participants, three patients with rheumatoid arthritis, and one patient each with polycystic ovarian syndrome, systemic lupus erythematosus, sarcoidosis or Sjogrens' syndrome) (Fig 1). Graves' disease patients did not differ significantly in their mean age, or male: female ratio from the control group of 13 participants (Table 1$)$. Mean endothelial cell activity $(30 \mu \mathrm{g} / \mathrm{mL}$ concentration of the protein-A eluate) did not differ significantly in Graves orbitopathy $(124 \pm 23 \%, \mathrm{~N}=9)$ compared to Graves without orbitopathy $(115 \pm 32 \%, \mathrm{~N}=9, \mathrm{P}=0.53)$. The mean thyroid stimulating hormone, thyroid stimulating immunoglobulin, antithyroid peroxidase antibody, or anti-thyroglobulin antibody levels did not differ significantly in active Graves' disease patients affected $(\mathrm{GO}+, \mathrm{N}=9)$ or not affected by orbitopathy (GO-, N = 9) (Table 1).

\section{Lack of association between EC activity in GD protein-A eluates and thyroid autoantibodies}

There was no significant correlation between thyroid stimulating immunoglobulin (TSI) level and endothelial cell growth activity in the protein-A eluates of all eighteen active GD sera (Fig 2A). There was no significant correlation between endothelial cell growth activity in the protein-A eluates of GD sera and either anti-thyroglobulin antibody $(\mathrm{n}=13)$ or anti-thyroid peroxidase antibody $(\mathrm{n}=15)$ level (Fig $2 \mathrm{~B}$, 
Mark B Zimering (2019) Endothelial Cell Growth Promoting Activity in Graves' Disease Sera is Neutralized by Anti-Basic Fibroblast Growth Factor Antibodies in Patients with Fat Expansive but Not Infiltrative Orbitopathy

2C). We next sought to characterize the endothelial cell growth stimulatory activity in the protein-A eluates of a subset of Graves' disease orbitopathy patients presenting with contrasting subtypes of ophthalmopathy, i.e. infiltrative vs. fat- expansion type.

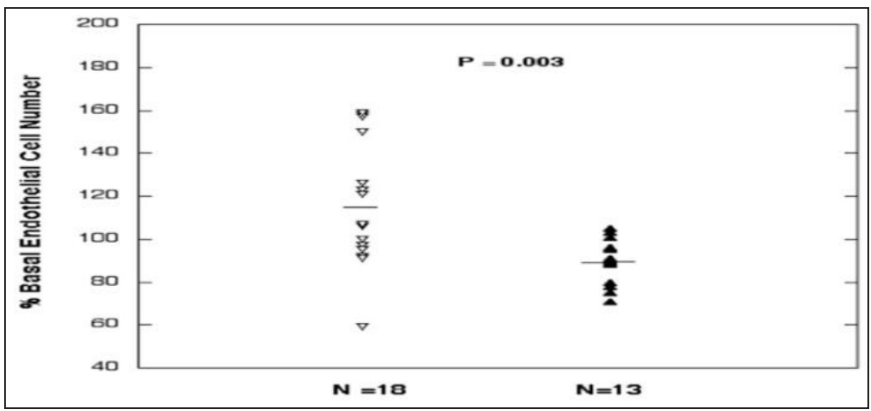

Figure 1. Endothelial cell growth-promoting activity in a one-fiftieth dilution $(30 \mu \mathrm{g} / \mathrm{mL})$ of the protein-A eluate fraction of serum from active Graves' disease (inverted, open diamonds) and control patients without Graves or thyroid disease (closed diamonds). Mean endothelial cell growth promoting activity in GD sera significantly exceeded activity in control sera. Bovine endothelial cells were incubated for four days in the presence of test fractions and $\%$ of basal activity was determined as described in Methods.

Table 1. Baseline characteristics in Graves' disease patients and control participants.

\begin{tabular}{|c|c|c|c|}
\hline Risk factor & Graves' disease $(\mathrm{N}=18)_{-}$ & $\begin{array}{c}\text { Systemic } \\
\text { autoimmunity } \\
\text { and normals } \\
(\mathrm{N}=13)\end{array}$ & P-value ${ }^{*}$ \\
\hline Age & $46.4(13.0)$ & $40.9(11.2)$ & 0.25 \\
\hline \multirow[t]{2}{*}{ Gender (M/F) } & $7 / 11$ & $5 / 8$ & $1.0 * *$ \\
\hline & $\mathrm{GO}+(\mathrm{N}=9) \mathrm{GO}-(\mathrm{N}=9)$ & & \\
\hline TSH $(\mu \mathrm{IU} / \mathrm{mL})$ & $2.28(3.19) 0.12(0.10)$ & NT & 0.09 \\
\hline TSI AB (\%) & $216(91) 241(110)$ & NT & 0.65 \\
\hline $\begin{array}{l}\text { Anti-TPO AB (IU/ } \\
\mathrm{mL})\end{array}$ & 1374(1449) 726(778) & NT & 0.32 \\
\hline $\begin{array}{l}\text { Anti-TG AB (IU/ } \\
\mathrm{mL})\end{array}$ & $42(50) 97(111)$ & NT & 0.35 \\
\hline \multicolumn{4}{|c|}{$\begin{array}{l}\text { Results are mean (SD); GO Graves orbitopathy, + present, -absent; M-male; } \\
\text { F-female }\end{array}$} \\
\hline \multicolumn{4}{|c|}{$\begin{array}{l}\text { TSH- thyroid stimulating hormone; TSI- thyroid stimulating immunoglobulin; TPO- } \\
\text { thyroid peroxidase; TG- thyroglobulin; AB-antibody. }\end{array}$} \\
\hline \multicolumn{4}{|c|}{$\begin{array}{l}\wedge \mathrm{N}=6 \text { normal participants, } 3 \text { rheumatoid arthritis, } 1 \text { systemic lupus erythematosus, } \\
1 \text { sarcoidosis, } 1 \text { polycystic ovarian syndrome, } 1 \text { Sjogren's syndrome patient. }\end{array}$} \\
\hline
\end{tabular}

\section{Endothelial cell activity in protein-A eluates of Graves'} disease having infiltrative vs. fat- expansion type orbitopathy

Active Graves' disease manifesting with moderately-severe acute infiltrative TAO, i.e. GD1, was characterized by extraocular muscle enlargement with subtle fatty degeneration in the lateral rectus muscle (Fig 3A). The GD1 protein-A eluate fraction contained a high titer of endothelial cell stimulatory activity (dashed black line, Fig 3C). Active Graves' disease presenting with globe prolapse, i.e. GD2, was characterized by severe orbital fat expansion (Fig 3B). The GD2 protein- A eluate contained a low-titer of endothelial cell inhibitory activity together with higher titer endothelial cell stimulatory $\operatorname{IgG}$ activity (GD Pt 2, dashed gray line, Fig 3C).

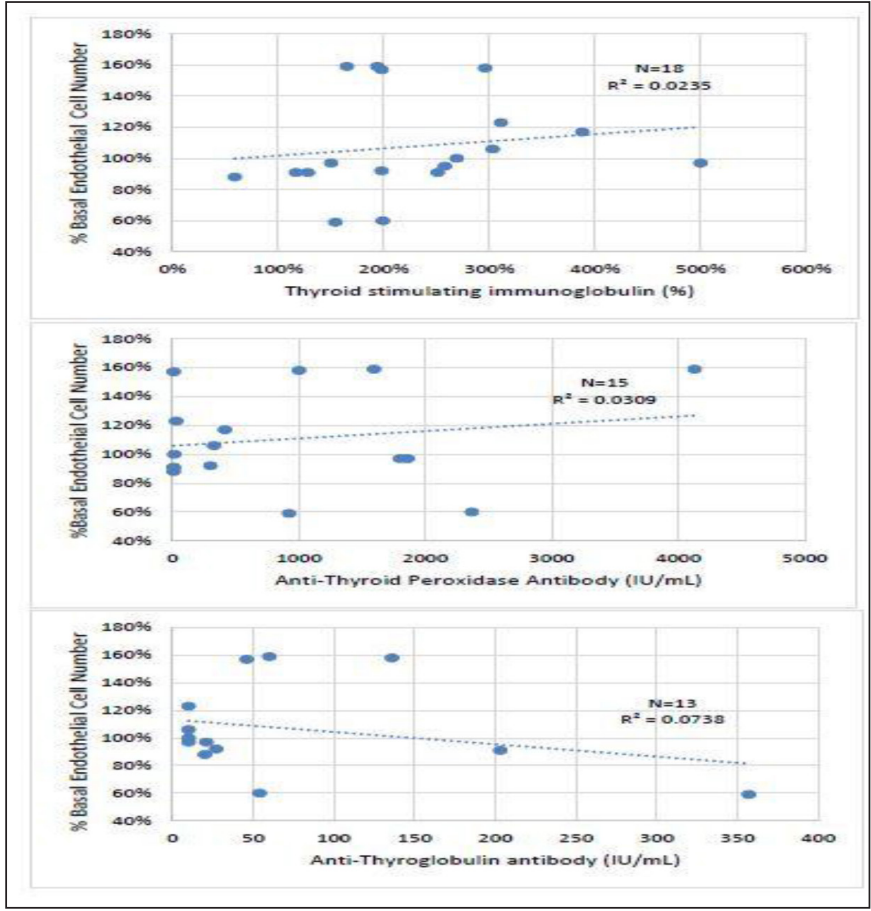

Figure 2. Correlation between endothelial cell growth promoting activity in the protein-A eluate of Graves' disease serum and level of A) thyroid stimulating immunoglobulin, B) anti-thyroid peroxidase antibody or $\mathrm{C}$ ) anti-thyroglobulin antibody. $\mathrm{R}^{2}=$ [correlation coefficient]. ${ }^{2}$

Patients who had experienced either long-standing infiltrativetype TAO (Pt 3) or orbital fat prolapse after receiving high-dose glucocorticoid therapy (Pt 4) were included as controls for the results in GD1 and GD2. The Pt 3, infiltrative-type TAO GD protein- A eluate contained a monophasic low titer of endothelial cell growth stimulatory activity (solid green line, Fig 3C), similar to GD1. The Pt 4, diabetic, orbital fat prolapse, protein- A eluate elicited biphasic endothelial cell- inhibitory and -stimulatory responses at low and higher titers, respectively (solid blue line, Fig 3C), similar to GD2.

A

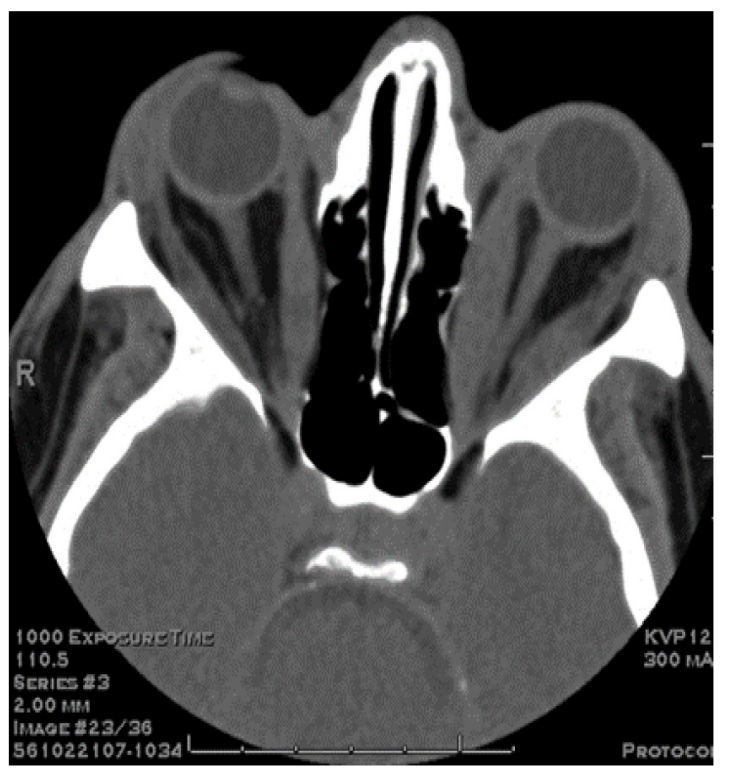


B

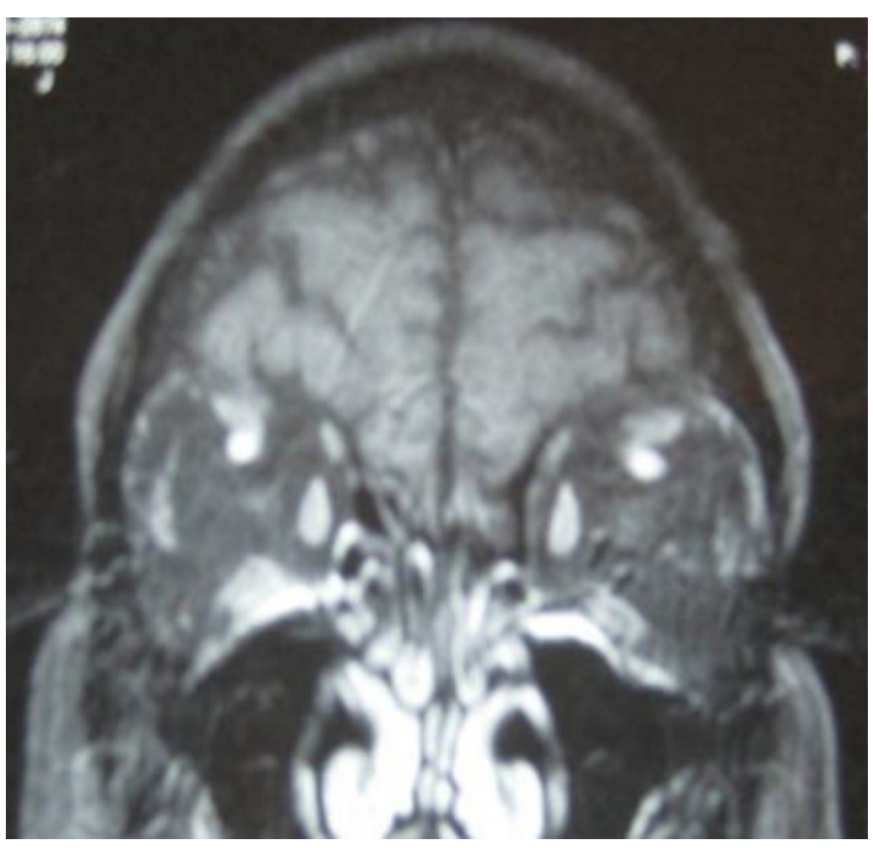

C

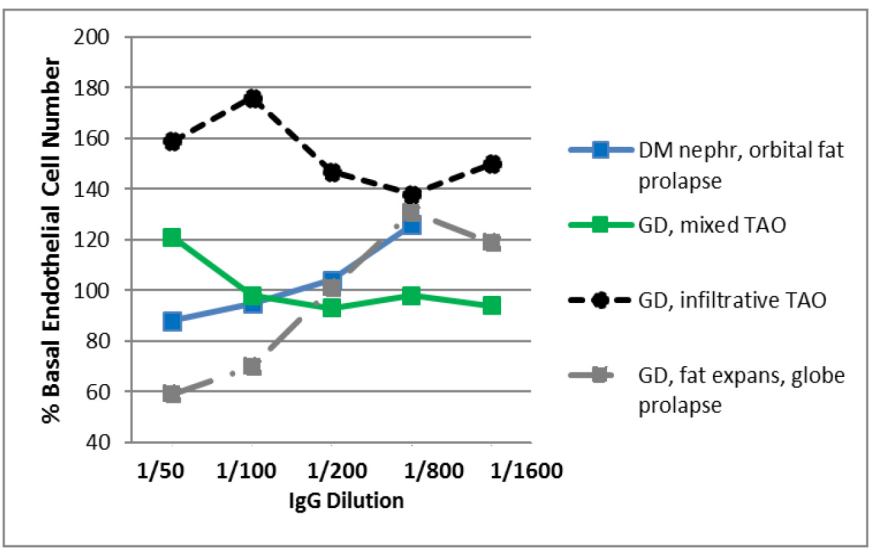

Figure 3. Contrasting infiltrative (A) and fat expansion (B) subtypes of thyroid associated ophthalmopathy and (C) corresponding dose-endothelial cell proliferation curves in protein-A eluates from patients having predominantly muscular hypertrophy or orbital fat expansion.

A) Computed tomography scan of the orbits (GD, Patient 1) showed bilateral proptosis, enlargement of the extraocular muscles sparing the tendons associated with fatty degeneration consistent with the clinical diagnosis of Graves ophthalmopathy. Optic nerves are within normal limits. B) Magnetic resonance imaging of the orbits (GD, Patient 2) revealed markedly increased retrobulbar fat bilaterally with resulting proptosis. The extraocular muscles and optic nerves were normal. Fat expansion caused complete loss of normal architecture of the orbit which together with shallow orbits predisposed to globe prolapse. C) Dose-endothelial cell proliferation curves of protein-A eluates in representative patients with Graves' disease having infiltrative-type orbitopathy (GD 1), retrobulbar fat expansion-type (GD2), or mixed infiltrative and fat expansion type orbitopathy (Pt 3); and in a diabetic nephropathy patient who experienced bilateral retrobulbar fat enlargement and orbital fat prolapse (Pt 4). Each point represents the mean of quadruplicate determinations which varied by $5-15 \%$. DM-diabetes mellitus, GDGraves disease, TAO-thyroid associated ophthalmopathy, expans(ion).

\section{Neutralization of EC bioactivity in GD with acute infiltrative TAO sera by anti-IGF1 receptor antibodies}

Peak endothelial cell stimulatory activity in the protein-A eluate from GD1 infiltrative-type TAO patient was significantly neutralized
$(\mathrm{P}<0.01))(\sim 67 \%)$ by co-incubation endothelial cells with a $5 \mu \mathrm{g} /$ $\mathrm{mL}$ concentration of monoclonal anti-human insulin-like growth factor 1 receptor (IGF1R) antibodies (e.g. Pt 1; Fig 4A). Seventy to one-hundred percent neutralization of endothelial cell activity (mean $123 \%$ ) was observed in the protein -A eluates in two additional GD patients (one each having mild GD orbitopathy or no orbitopathy) following co-incubation with $(5 \mu \mathrm{g} / \mathrm{mL})$ monoclonal anti- human IGF1R antibodies (data not shown in Fig 4). The anti-IGF1R antibodies alone had no significant effect on EC proliferation (Fig 4A). Endothelial cell stimulatory activity in the protein- A eluate of GD1 was not significantly affected by co-incubation with a $5 \mu \mathrm{g} / \mathrm{mL}$ concentration of specific anti-bovine basic fibroblast growth factor (bFGF) antibodies (Fig 4B).

A

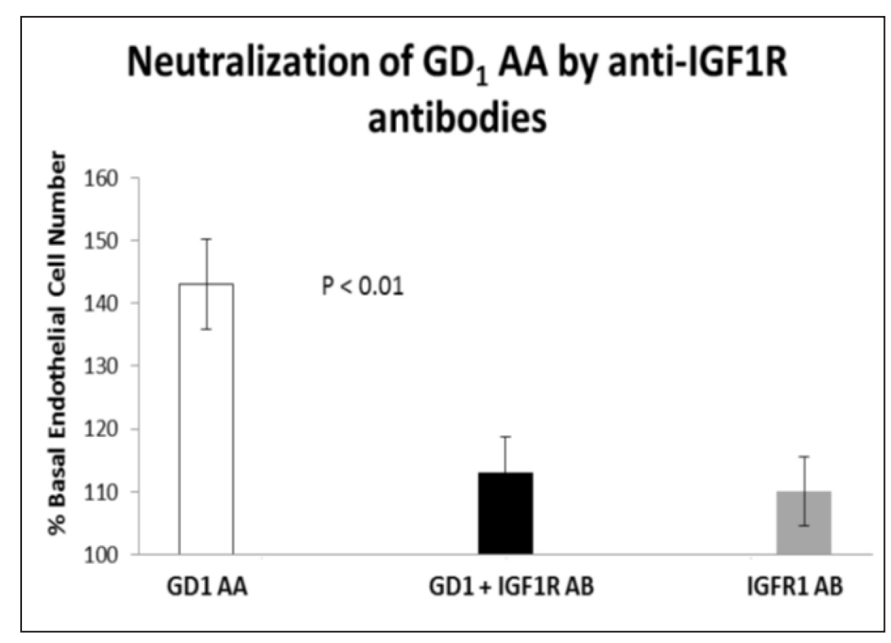

B

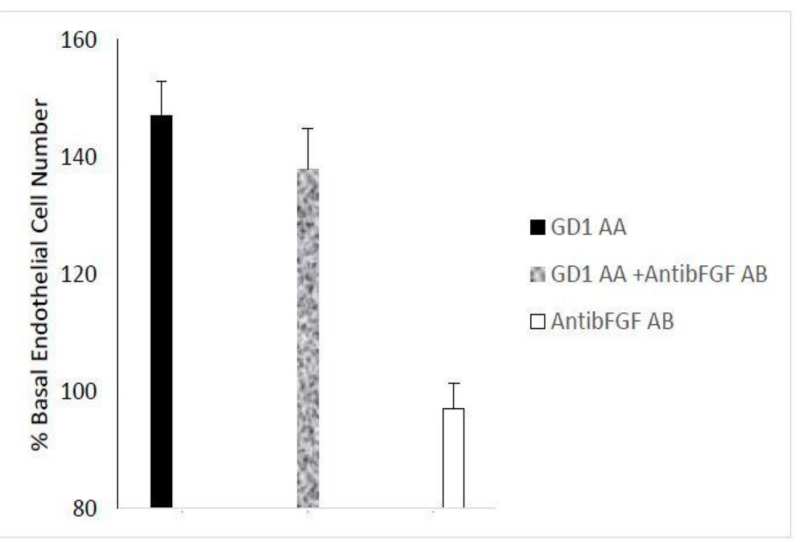

Figure 4. Neutralization of GD1 infiltrative-type ophthalmopathy autoantibodies by specific insulin-like growth factor 1 receptor antibodies.

Neutralization of endothelial cell proliferative activity in A) GD1 protein-A eluate fraction by specific anti-insulin like growth factor 1 receptor antibodies. Similar results were observed in three Graves' disease patients tested. B) Lack of effect of specific antibFGF antibodies on endothelial cell growth promotion by Graves' disease protein-A eluate autoantibodies. A, B) Ten micrograms $/ \mathrm{mL}$ concentrations of the protein-A eluate from $\mathrm{Pt}$ 1 , Graves' disease serum was incubated in the presence (black bar) or absence (open bar) of $5 \mu \mathrm{g} / \mathrm{mL}$ concentrations of anti- IGF1R antibodies (A) or $5 \mu \mathrm{g} / \mathrm{mL}$ concentrations of anti-bFGF antibodies (B). Each point represents the mean $(+\mathrm{SD})$ of quadruplicate determinations as described in Methods. AA-autoantibodies, IGF1R-insulin-like growth factor 1 receptor, GD1- Graves' disease patient 1, AB-antibodies, AntibFGF AB- antibasic fibroblast growth factor antibodies. 


\section{Neutralization of EC bioactivity in GD with retrobulbar fat expansion TAO sera by specific anti- bFGF antibodies}

Peak EC stimulatory activity in the protein-A eluate from GD Patient 2 suffering globe prolapse was completely neutralized by coincubation with $5 \mu \mathrm{g} / \mathrm{mL}$ anti-bovine basic fibroblast growth factor antibodies (Fig 5A). The anti-bFGF antibodies alone had no significant effect on endothelial cell proliferation (Fig 5A). Co-incubation with a $5 \mu \mathrm{g} / \mathrm{mL}$ concentration of monoclonal anti-human insulin-like growth factor 1 receptor antibodies had no significant effect on endothelial stimulatory activity in the GD Patient 2 protein-A eluate fraction (data not shown in Fig 5). Peak EC stimulatory activity in the protein- A eluate fraction in Pt 4 suffering orbital fat prolapse was completely neutralized following co-incubation with $5 \mu \mathrm{g} / \mathrm{mL}$ specific anti- bFGF antibodies (Fig 5B).

A

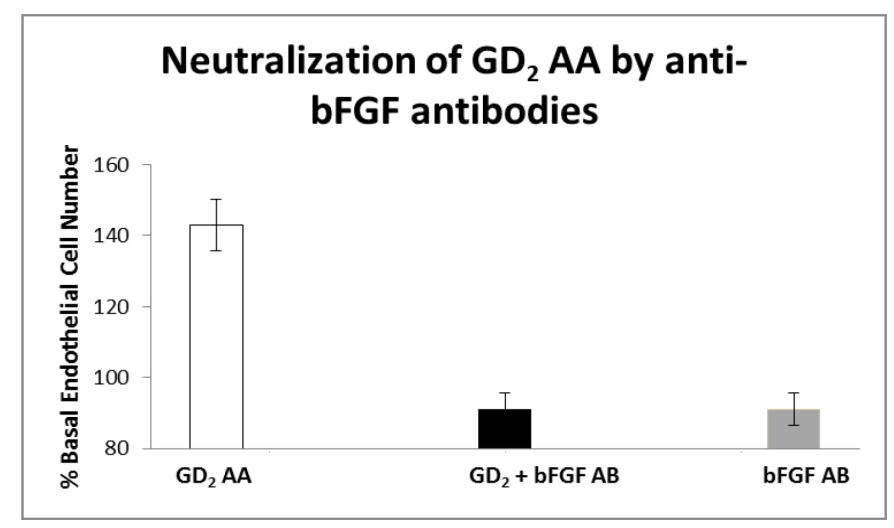

B

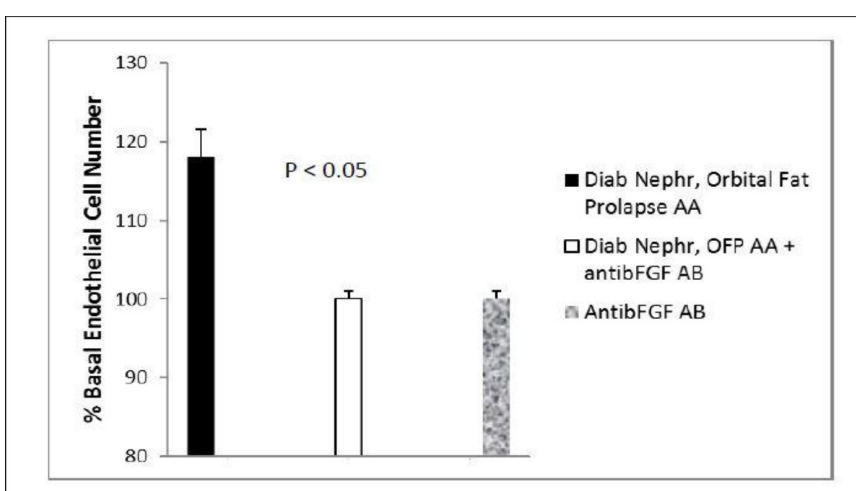

Figure 5. Neutralization of fat-expansion type ophthalmopathy autoantibodies by antibasic fibroblast growth factor antibodies.

Neutralization of endothelial cell proliferative activity in A) GD2 protein- A eluate fraction or B) Pt 4 diabetic nephropathy, orbital fat prolapse patient's protein- A eluate fraction by specific anti-bFGF antibodies. B) Two micrograms $/ \mathrm{mL}$ concentrations of the protein-A eluate from GD, Pt 2 or Pt 4 serum was incubated in the presence (black bar) or absence (open bar) of $5 \mu \mathrm{g} / \mathrm{mL}$ concentrations of specific anti-bovine bFGF antibodies as described in Methods. Complete neutralization of endothelial cell growth stimulatory activity was observed in the protein-A eluates from GD2 and Pt 4 diabetic nephropathy patient suffering with idiopathic retrobulbar fat expansion and fat prolapse. Each point represents the mean $( \pm \mathrm{SD})$ of quadruplicate determinations. GD2-Graves' disease, Patient 2, Diab Neph(ropathy), OFP AA- orbital fat prolapse autoantibodies.

\section{Discussion}

The present data are the first to suggest increased circulating endothelial cell stimulatory autoantibodies in active Graves' disease.
Angiogenesis is a characteristic feature of the thyroid gland in Graves' disease as evidenced by a characteristic "thyroid inferno" color Doppler flow sonography pattern [6] in Graves' disease patient 2 in the present study. Goiter formation in the rat was accompanied by increased basic fibroblast growth factor expression in the thyroid follicular cells, stroma and endothelial cells as well as neovascularization [7]. Basic fibroblast growth factor (basic FGF) is a highly potent autocrine endothelial cell mitogen which lacks an amino terminal signal sequence needed for efficient secretion from cells [8]. Basic fibroblast growth factor does not normally circulate in healthy, nonpregnant adults $[9,10]$, however, plasma basic fibroblast growth factor immunoreactivity was increased in certain pituitary tumors, e.g. sporadic acromegaly [9] and in micro- or albuminuric diabetic nephropathy [11]. The occurrence of fibroblast growth factor-like autoantibodies in subsets of sporadic acromegaly [12] and in diabetic nephropathy [13] suggested a role for elevated insulin-like growth factor 1 [14] or chronic inflammation in enhanced autoantibody production [14] to circulating basic fibroblast growth factor or its receptors. The present data are the first to suggest that fibroblast growth factor-like autoantibodies in diabetic nephropathy suffering with co-morbid Graves' disease or a different systemic autoimmune disease may be a driver of orbital fat expansiontype orbitopathy.

Prior reports suggested a possible local role for angiogenic factors such as basic fibroblast growth in promoting Graves' orbitopathy. For example, basic fibroblast growth factor expression was increased in the orbital fibroblasts and adipocytes of patients suffering with severe Graves' orbitopathy [15]. In addition, basic FGF acted synergistically with platelet derived growth factor in promoting orbital fibroblast production of hyaluronan and interleukin-6 [16]. Macrophages present in chronically- inflamed Graves' orbital tissues [15] express a number of different angiogenic factors including basic FGF and insulin-like growth factor 1 [17]. Increased expression of insulinlike growth factor 1 receptor on $\mathrm{T}$ and $\mathrm{B}$ lymphocytes reported in Graves' disease [4] may provide a mechanism for enhanced systemic autoimmunity to locally- or systemically-elaborated basic FGF via activation of the insulin-like growth factor 1 receptor on immune cells by subsets of circulating Graves' disease immunoglobulins [18]. Although endothelial cell stimulatory autoantibody activity was not preferentially increased in a subset of Graves' orbitopathy vs. Graves' without orbitopathy in the present study, the sample sizes were small precluding a definitive conclusion.

In acute severe infiltrative Graves' orbitopathy (GD patient 1), autoantibody-mediated endothelial cell stimulatory activity was neutralized $(\sim 67 \%)$ by specific anti-insulin-like growth factor 1 receptor antibodies, but was unaffected by specific anti-basic fibroblast growth factor antibodies. The autoantibody-mediated endothelial cell stimulatory activity in two of two additional newly-diagnosed Graves' disease sera tested was also substantially or completely blocked by specific anti-insulin-like growth factor antibodies suggesting that fibroblast growth factor-like autoantibodies are not likely to play a significant role in early, active Graves' disease patients lacking comorbid diabetic nephropathy. Endothelial cell inhibitory autoantibody activity was largely absent in the protein-A eluates in seventeen of eighteen active Graves' disease patients (Fig 1) consistent with a prior 
report of a low prevalence of anti-endothelial cell autoantibodies in thyroid autoimmunity patients having suppressed TSH [19]. Antiendothelial cell autoantibodies were reported to occur at a (four-fold) significantly higher prevalence in thyroid autoimmunity patients having elevated TSH [19]. This may explain in part an increased occurrence of low-titer anti-endothelial cell autoantibodies in previously-treated, chronic Graves' disease patients compared to newly-diagnosed Graves' disease. In subsets of diabetic macular edema [20] and/or diabetic nephropathy [13] anti-endothelial cell autoantibodies targeted heparan sulfate proteoglycan, the low affinity FGF receptor, which is required for FGF-mediated endothelial cell survival and proliferation [21].

A possible dual role for endothelial cell inhibitory and fibroblast growth factor like stimulatory autoantibodies in promoting orbital fat expansion (in the setting of high-dose glucocorticoid therapy) is suggested by several observations. First, abrogation of basic fibroblast growth factor signaling (via knockout of the FGF2 gene in mice), promoted differentiation of bone marrow stromal cells into adipocytes [22]. Second, dexamethasone is known to promote adipocyte differentiation in pluripotent mesenchymal stem cells which have the potential to develop into osteoblasts or fat cells [23]. Third, basic fibroblast growth factor is a mitogen abundantly expressed in osteoblasts [24] and in preadipocytes [25], and in the latter cell type, basic fibroblast growth factor prevented adipocyte differentiation [25]. Taken together, fibroblast growth factor-like autoantibodies might drive expansion in a pool of precursor cells which later differentiate into fat cells under the dual influences of high-dose glucocorticoids and FGF- inhibitory autoantibodies. This proposed mechanism requires spatially- and temporally- independent actions by FGF-inhibitory and -stimulatory autoantibodies. Since FGF-like stimulatory, but not inhibitory autoantibodies displayed uniquely high affinity for hydroxyapatite which is a normal constituent of bone matrix [5] stimulatory autoantibodies might localize to a different region in the orbital- retro-orbital connective tissue space than soluble FGF-inhibitory autoantibodies.

The etiology of muscle enlargement in thyroid-associated ophthalmopathy is still a subject of debate with evidence supporting involvement of either TSH receptor autoantibodies and/or insulinlike growth factor 1 receptor autoantibodies [18]. A ten nanomolar concentration of insulin-like growth factor 1 was reported to cause an $80 \%$ increase in basal DNA synthesis in microvascular endothelial cells [26] and phosphorylation of the insulin-like growth factor 1 receptor in macrovascular endothelial cells [27]. Thus a subset of Graves' disease IgG autoantibodies having specificity for the insulinlike growth factor 1 receptor may have accounted (in part) for the significant endothelial cell proliferation we observed here in a subset of newly-diagnosed Graves' disease patients with infiltrative-type orbitopathy.

In summary, these data are the first to suggest a possible association between fibroblast growth factor-like stimulatory autoantibodies and subsets of orbital fat-expansion/fat prolapse in patients with Graves' disease, diabetes and focal segmental glomerulosclerosis or in diabetes having a different systemic autoimmune co-morbid condition which also required treatment with high-dose glucocorticoids. More study is needed to determine whether coexisting endothelial cell inhibitory and stimulatory autoantibodies in Graves' disease serum may be a useful biomarker for an increased risk of fat expansion- type orbitopathy following high-dose glucocorticoid therapy.

\section{Acknowledgement}

Presented in part at the 92nd Annual Meeting of the Endocrine Society, Boston, MA. June 4, 2011. We thank Terry J. Smith, MD for his valuable contributions to an earlier draft of the manuscript.

The authors report no multiplicity of interest affecting the objectivity of the presented findings. Supported in part by a grant from the Veterans Biomedical Research Institute, East Orange, New Jersey, USA to MBZ.

\section{Abbreviations}

BPA - Bovine Pulmonary Artery

EC - Endothelial Cells

FCS - Fetal Calf Serum

FGF2 - Fibroblast Growth Factor 2

bFGF - basic Fibroblast Growth Factor

FSGS - Focal Segmental Glomerulosclerosis

GD - Graves' Disease

IGF1 - Insulin-Like Growth Factor 1

IGF1R - Insulin-Like Growth Factor 1 Receptor

M199 - Medium 199

TAO - Thyroid Associated Ophthalmopathy

T3 - Triiodothyronine IgG-Immunoglobulin G

\section{References}

1. Hiromatsu Y, Eguchi H, Tani J, Kasaoka M, Teshima Y (2014) Graves' ophthalmopathy: epidemiology and natural history. Intern Med 53: 353-360. [crossref]

2. Tsui S, Naik V, Hoa N (2008) Evidence for an association between thyroidstimulating hormone and insulin-like growth factor 1 receptors: a tale of two antigens implicated in Graves' disease. J Immunol 181: 4397-4405.

3. Smith TJ, Hegedüs L, Douglas RS (2012) Role of insulin-like growth factor-1 (IGF-1) pathway in the pathogenesis of Graves' orbitopathy. Best Pract Res Clin Endocrinol Metab 26: 291-302. [crossref]

4. Douglas RS, Naik V, Hwang (2008) CJ B cells from patients with Graves' disease aberrantly express the IGF-1 receptor: implications for disease pathogenesis. $J$ Immunol 181: 5768-5774.

5. Zimering MB, Thakker-Varia S (2002) Increased fibroblast growth factorlike autoantibodies in serum from a subset of patients with cancer-associated hypercalcemia. Life Sci 71: 2939-2959.

6. Ralls PW, Mayekawa DS, Lee KP, Colletti PM, Radin DR, et al. (1988) Color-flow Doppler sonography in Graves disease: "thyroid inferno". AJR Am J Roentgenol 150: 781-784. [crossref]

7. Patel VA, Hill DJ, Eggo MC, Sheppard MC, Becks GP, et al. (1996) Changes in the immunohistochemical localisation of fibroblast growth factor-2, transforming growth factor-beta 1 and thrombospondin- 1 are associated with early angiogenic events in the hyperplastic rat thyroid. $J$ Endocrinol 148: 485-499. [crossref]

8. Abraham JA, Mergia A, Whang JL (1986) Nucleotide sequence of a bovine clone encoding the angiogenic protein, basic fibroblast growth factor. Science 233: 545548 .

9. Zimering MB, Katsumata N, Sato Y, Brandi ML, Aurbach GD, et al. (1993) Increased basic fibroblast growth factor in plasma from multiple endocrine neoplasia type 1 : relation to pituitary tumor. J Clin Endocrinol Metab. 76: 1182-1187.

10. Hill DJ, Tevaarwerk GJ, Caddell C, Arany E, Kilkenny D, et al. (1995) Fibroblast growth factor 2 is elevated in term maternal and cord serum and amniotic fluid in 
Mark B Zimering (2019) Endothelial Cell Growth Promoting Activity in Graves' Disease Sera is Neutralized by Anti-Basic Fibroblast Growth Factor Antibodies in Patients with Fat Expansive but Not Infiltrative Orbitopathy

pregnancies complicated by diabetes: relationship to fetal and placental size. J Clin Endocrinol Metab 80: 2626-2632. [crossref]

11. Zimering MB, Eng J (1996) Increased basic fibroblast growth factor-like substance in plasma from a subset of middle-aged or elderly male diabetic patients with microalbuminuria or proteinuria. J Clin Endocrinol Metab 81: 4446-4452. [crossref]

12. Zimering MB, Katsumata N, Friesen HG (1997) Fibroblast growth factor-like autoantibodies in plasma from patients with multiple endocrine neoplasia type 1 and prolactinoma. In, B Lymphocytes and Autoimmunity Ann NY Acad of Sciences 815: $520-524$.

13. Zimering MB, Zhang JH, Guarino PD, Emanuele N, McCullough PA, et al. (2014) Investigators for the VA NEPHRON-D. Endothelial cell autoantibodies in predicting declining renal function, end-stage renal disease, or death in adult type 2 diabetic nephropathy. Front Endocrinol (Lausanne) 5: 128.

14. Robbins K, McCabe S, Scheiner T, Strasser J, Clark R, et al. (1994) Immunological effects of insulin-like growth factor-I--enhancement of immunoglobulin synthesis. Clin Exp Immunol 95: 337-342. [crossref]

15. Pawlowski P, Reszec J, Eckstein A (2014) Markers of inflammation and fibrosis in the orbital fat/connective tissue of patients with Graves' orbitopathy: clinical implications. Mediators Inflamm 412158.

16. Virakul S, Heutz JW, Dalm VA (2016) Basic FGF and PDGF-BB synergistically stimulate hyaluronan and IL-6 production by orbital fibroblasts. Mol Cell Endocrinol 433: 94-104.

17. Sunderkötter C, Goebeler M, Schulze-Osthoff K, Bhardwaj R, Sorg C (1991) Macrophage-derived angiogenesis factors. Pharmacol Ther 51: 195-216.

18. Smith TJ (2003) The putative role of fibroblasts in the pathogenesis of Graves' disease: evidence for the involvement of the insulin-like growth factor-1 receptor in fibroblast activation. Autoimmunity 36: 409-415.
19. Wangel AG, Kontiainen S, Melamies L, Weber T (1993) Hypothyroidism and antiendothelial cell antibodies. APMIS 101: 91-94. [crossref]

20. Zimering MB, Anderson RJ, Moritz TE, Ge L (2009) Investigators for the VADT. Endothelial cell inhibitory autoantibodies are associated with laser photocoagulation in adults from the Veterans Affairs Diabetes Trial. Metabolism 58: 882-887.

21. Zimering MB, Pan Z (2009) Autoantibodies in type 2 diabetes induce stress fiber formation and apoptosis in endothelial cells. J Clin Endocrinol Metab 94: 21712177.

22. Xiao L, Sobue T, Esliger A, Kronenberg MS, Coffin JD, et al. (2010) Disruption of the Fgf2 gene activates the adipogenic and suppresses the osteogenic program in mesenchymal marrow stromal stem cells. Bone 47: 360-370. 360-370. [crossref]

23. Q Chen, P Shou, C Zheng, M Jiang, G Cao, et al. (2016) Fate decision of mesenchymal stem cells: adipocytes or osteoblasts? Cell Death Differ 23: 11281139 .

24. Marie PJ (2012) Fibroblast growth factor signaling controlling bone formation: an update. Gene 498: 1-4. [crossref]

25. Teichert-Kuliszewska K, Hamilton BS, Deitel M, Roncari DA (1994) Decreasing expression of a gene encoding a protein related to basic fibroblast growth factor during differentiation of human preadipocytes. Biochem Cell Biol 72: 54-57.

26. Bäck K, Islam R, Johansson GS, Chisalita SI, Arnqvist HJ (2012) Insulin and IGF1 receptors in human cardiac microvascular endothelial cells: metabolic, mitogenic and anti-inflammatory effects. J Endocrinol 215: 89-96.

27. Chisalita SI, Arnqvist HJ (2004) Insulin-like growth factor I receptors are more abundant than insulin receptors in human micro- and macrovascular endothelial cells. Am J Physiol Endocrinol Metab 286: 896-901.

Citation:

Mark B Zimering, John J Shin, Jennifer D Zaitz, Elkin A Nunez and Andrew G Gianoukakis (2019) Endothelial Cell Growth Promoting Activity in Graves’ Disease Sera is Neutralized by Anti-Basic Fibroblast Growth Factor Antibodies in Patients with Fat Expansive but Not Infiltrative Orbitopathy. Endocrinol Diabetes Metab $J$ Volume 3(1): 1-7. 